\title{
Genes in time and in space
}

\section{R.J. Berry}

Ecological Genetics. By David J. Merrell. Pp.500. UK ISBN 0-582-46349-1; US ISBN 0-8166-1019-3. (Longman/University of Minnesota Press: 1982.) $115, \$ 25$.

THIS is almost a very good book. Merrell has set out to write the sort of textbook which includes new ideas as well as regurgitated concepts and examples. In his case, the positive intention has been to consummate a union between population genetics and population ecology. As he says, this has been delayed for a number of reasons, not least because "population geneticists often assume a constant environment while population ecologists usually assume that all members of a population have identical genotypes". His explicit object is to bring together the results and concepts of ecologists and geneticists into one coherent whole.

This aim is well worthwhile: unexplained ecological variation may be largely due to genetic heterogeneity, whilst the models of geneticists need frequent tempering with muddy reality. Indeed, population biologists have caused problems for themselves because individuals, eminent and erudite though they may be, have repeatedly failed to see their organism - or population(s) - in all its relevant complexity: de Vries thought species arise through saltation (a misapprehension still being debated); the attitude of antagonists in the neutralism-selection debate of the 1970s could be predicted from their scientific background (the argument was really one between theoreticians and naturalists); life-table determination has often seemed to be an end in itself, although any lifetable is dependent on environmental, biotic and genetic interactions; and so on.

Merrell has attempted to make sense of these many-sided confusions. He has not quite succeeded. One reason is that he is more familiar with Drosophila than the rest of the living world put together (although he has also worked with frogs), and he tends to use unadorned citations to illustrate his arguments, rather than developing relevant examples; another is his restricted choice of examples, in many cases referring to early work only. For example, Cepaea nemoralis is one of the few species where ecology has been fairly closely linked with genetics, but no paper more recent than 1968 is mentioned; no reference is made to speciation in Partula; and Hawaiian Drosophila is only noted in passing.

But perhaps the real reason for Merrell's failure is that ecological genetics itself may not yet have come of age; perhaps its components need to develop in their own right before they can be brought together. If so, Merrell's book may be a useful catalyst, as was Dobzhansky's Genetics and the Origin of Species to a previous generation. Ecological Genetics represents a noble attempt at synthesis. It could be improved fairly simply by including and expanding upon more biological examples; some sections are very good (such as those on dominance and competition), whilst others ramble somewhat and need shortening (the neutralism chapter is far too long, while the evolutionary implications of MacArthur and Wilson's theory of island biogeography are not explored); and the book needs up-dating (there are references to 1978 , but the main literature survey stops at 1976).

As it stands, the first edition of Ecological Genetics should be skimmed through by population ecologists and geneticists sensu stricto; but properly revised the second edition could easily become required reading for that significant part of the biological community which acknowledges the existence of a world beyond the laboratory.

Sam Berry is Professor of Genetics at University College London. He is the author of Inheritance and Natural History (Collins, 1977) and NeoDarwinism (Edward Arnold, 1982).

\section{Chemistry at war}

\section{Alastair Hay}

A Higher Form of Killing. By Robert Harris and Jeremy Paxman. Pp.288. ISBN 0-701 1-2585-3. (Chatto \& Windus/Hill \& Wang: 1982.) $£ 9.95, \$ 14.95$.

CHEMICAL warfare is a subject which arouses fierce passions. Its apologists claim that it is both efficient and "humane"; it affects people but not objects, and it injures more than it kills. Victims of gas poisoning on the other hand, would probably prefer to quote evidence from an expert on the subject, Wilfred Owen:

\section{Gas! Gas! Quick boys - An ecstasy of} fumbling,

Fitting the clumsy helmets just in time; But someone still was yelling out and stumbling, And floundering like a man in fire or lime . . . Dim, through the misty panes and thick green light,

As under a green sea, I saw him drowning.

One person who did not see gas warfare through Owen's eyes was Fritz Haber. The 1919 Nobel Prize winner in chemistry for his part in the Haber-Bosch process - the conversion of nitrogen to ammonia Haber was also the pioneer of modern gas warfare. To him it was "a higher form of killing'". This was how he described it in the acceptance speech in Stockholm after the war, and his phrase provides Robert Harris and Jeremy Paxman with their title.

Recent allegations about the use of chemical and biological warfare (CBW) and the history of the development of such weapons form the basis of their account. The book is not a comprehensive treatise on CBW - that would be impossible to write in a single volume - it is more of an outline of the subject, except where it deals with the development of CBW in Britain during the Second World War. Here the authors have retrieved previously classified material and they deal with British war preparations in absorbing detail.

Appropriately, Harris and Paxman begin with the use of poison gas - by the German army - near Ypres in April 1915. They describe the military consequences in some detail, but any lasting impression of the use of chemical warfare in the fields of France and Flanders must be of the appalling casualties these weapons caused. Officially, 180,983 British soldiers were gassed, of whom some 6,062 died. According to the authors, however, the statistics are far from complete. They omitted numbers of men gassed in 1915; gas casualties found by the enemy; any of the quarter-of-a-million British soldiers missing in action; any soldiers who were killed in action; or even gas casualties who died after being evacuated to Britain. As for the German and Russian records, these are probably equally unreliable. In view of this, any argument about the supposedly "humane" features of chemical weapons which uses statistics from the First World War to prove that the weapons injure, rather than kill, should be treated with some caution.

The Germans may have been the first to use gas, but the Allies were not slow to respond. As the war progressed more sophisticated chemical weapons emerged from the laboratories of both sides, thousands of scientists and soldiers being recruited to screen chemicals for the ideal weapon. After chlorine, came phosgene; mustard gas followed phosgene. Because the gas was not visible, most troops failed to even don their gas masks. By the following morning most were almost blind and in the ensuing days, many died, like other cases of gas poisoning, with lungs and throat stripped of any lining and heavily congested.

During the First World War, the disadvantages of chemical weapons - problems in deploying them and fear of retaliation in kind - had become apparent. Nonetheless, in 1940, it is clear that Winston Churchill saw them as adding

A second edition of T.G.R. Bower's Development in Infancy has just been published by W.H. Freeman. On its first appearance in 1974, Jerome Bruner judged the work to be "one of the major books on human development to be written during the last decade"' (Nature 252, 514; 1974). Prices of the new edition are hbk $£ 14.80, \$ 20$; pbk £6.90, $\$ 9.95$. 
diversity to Britain's arsenal. He was keen that Britain should have adequate supplies of the weapons if only as a deterrent, to which his constant stream of memos to the Ministry of Supply to "press on" with the production of these weapons bears testimony.

All this is a matter of public record. But in their book, Harris and Paxman break new ground by claiming that Churchill was not only interested in chemical weapons as a deterrent; he was also prepared for Britain to initiate gas warfare. Had Germany invaded Britain in 1940 , or 1941 , the authors say that chemical warfare would probably have ensued. In addition, they claim that Churchill was convinced that chemical weapons could be used in Europe to the Allies advantage, but that this idea was firmly rebuffed by his Chiefs of Staff.

The controversial memos cited in $A$ Higher Form of Killing show just how close Britain camc to using CBW in the Second World War. But the fact remains that it was not. The Japanese, however, were not quite so inhibited. Recent documents published in the United States and given wide publicity in Japan are noted by the authors. These confirm that Japan conducted biological warfare against various cities in China. Further, Japanese scientists tested biological weapons in sickening experiments on prisoners of war in China in the early 1940s, the organisms involved including anthrax, cholera, plague, hemorrhagic fever, smallpox, typhoid, typhus and gas gangrene. To study the progress of the disease some subjects were killed - with morphine - at various times and autopsied. A great deal of this research material was collected by the United States at the end of the war, for which it appears that the prosecutors did a deal with the Japanese scientists: immunity from prosecution in exchange for research data. According to a memo from Dr Edwin V. Hill, then chief of Basic Sciences at Camp Detrick in Maryland - the research centre for biological weapons in the United States - the data was invaluable because they "could not be obtained in our own laboratories because of scruples attached to human experimentation". Hill went on to say that he "hoped that individuals who voluntarily contributed this information will be spared embarrassment because of it"'.

In bringing their story closer to the present, the authors are inaccurate on some points. For example, on the question of the use - by the United States - of chemical agents in IndoChina, Cambodia was never heavily sprayed with defoliants; there is only one documented spraying incident. And as for the evidence that herbicide spraying led to a three-fold increase in the number of children born malformed in South Vietnam, this is still controversial. But these are relatively minor points. From the evidence cited by Harris and Paxman one needs little convincing that there are

\section{Science Books International, Publishers presents:}

\begin{tabular}{|c|c|}
\hline $\begin{array}{l}\text { iken with the } \\
\text { rm a stunnıng } \\
\text { of the best } \\
\text { See plants. } \\
\text { gnified up to } \\
\text { roduced } \\
\text { escriptive cap- } \\
\text { The reader } \\
\text { tistic quality }\end{array}$ & 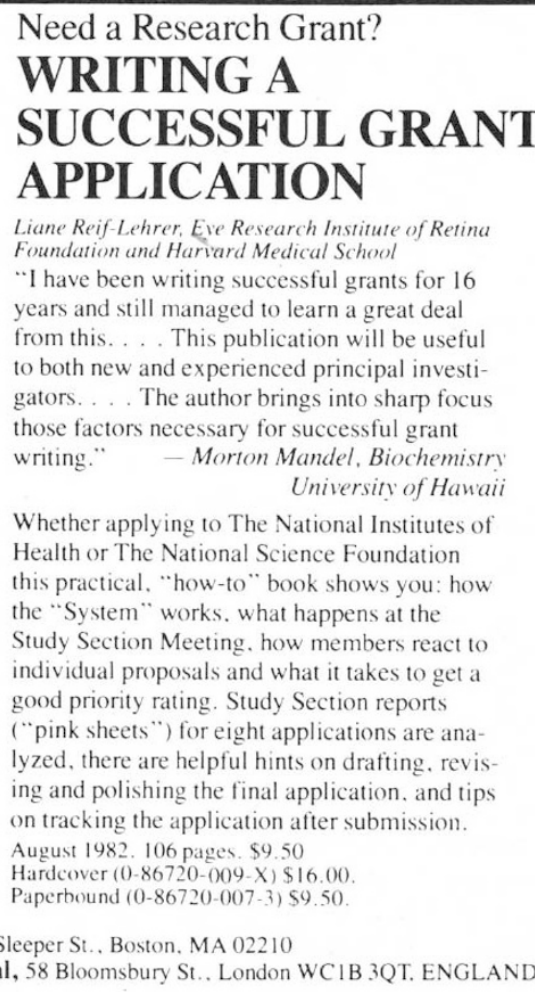 \\
\hline
\end{tabular}

Circle No.12 on Reader Service Card. deficiencies in the 1925 and 1972 Geneva protocols outlawing the use of chemical and biological weapons respectively.

A major flaw of both agreements is the inadequacy of their provisions for verifying that violations have occurred. The most recent allegations by the United States that the Soviet Union and her allies are waging chemical, and possibly biological warfare in Afghanistan, Laos and Kampuchea only serve to highlight the need for the protocols to be made watertight. The allegations - and they remain no more than this - are immensely difficult to verify. The Soviet Union and Vietnam deny most emphatically that they are using chemical weapons; they claim that these accusations are being used by the United States as a smokescreen to justify its own development of a new generation of binary nerve gas weapons; weapons in which the nerve agent is actually made in the shell or bomb en route to its target.

Both the Soviet Union and United States speak of the need to negotiate a treaty outlawing the use of CBW. With the Americans pushing ahead with the development of binary weapons it clearly is in everyone's interest that the bilateral negotiations between these two powers suspended temporarily, because the United States has withdrawn its negotiators should be successfully concluded.

Churchill had a vision of an enemy only being temporarily indisposed after a chemical attack. This was always rather optimistic and it would certainly never hold true for the current generation of weapons. Nerve gases kill; and in any chemical war in Europe most of the casualties will be civilians. A Higher Form of Killing will certainly help drive that message home.

Alastair Hay is a Lecturer in the Department of Chemical Pathology at the University of Leeds.

\section{Plant production put in harness}

\section{J. Barber}

Techniques in Bioproductivity and Photosynthesis. Edited by J. Coombs and D.O. Hall. Pp.171. Hbk ISBN 0-08-027382-3; pbk ISBN 0-08-027383-1. (Pergamon: 1982.) Hbk \$36, £15; pbk \$16, $£ 7.50$.

THIS book, essentially a comprehensive laboratory manual, has been put together as a result of a United Nations sponsored course aimed to provide training in basic techniques for measurement of plant productivity. There are 17 contributors, all of whom were involved in teaching the course which so far has been held in India, Kenya and Yugoslavia. 